\title{
\# The late Professor G. A. Costanzo: A Tribute
}

Qui d'entre nous, à Rome, ily a moins de six semaines, auraitpuimaginer en le quittant que c'était à jamais? Qui aurait accepté de croire un seul instant que la merveilleuse chaleur humaine qu'il irradiait s'éteindrait tout à coup sans que nous puissions espérer la ranimer? Et cependant il faut nous y résigner. Notre ami Giuseppe Aurelio Costanzo ne nous accueillera plus jamais de son immense sourire, et Rome, malgré tout son attrait ne sera plus jamais, pour beaucoup d'entre nous, tout à fait la même. L'Association internationale de droit africain perd l'un de ses Vice-Présidents les plus actifs et les plus dévoués à la cause commune, sa section italienne son infatigable animateur, la Faculté des Sciences politiques de l'Université de Pérouse un doyen dont le terme s'annonçait riche en réalisations de toutes espèces et nous tous enfin un ami très cher. En outre, ses publications sont là pour nous rappeler l'homme de science que passionnait le développement juridique africain, de même que les conférences de Rome de 1971 et $197^{2}$ porteront témoignage de sa volonté de voir son pays reprendre dans ce domaine la place qui devait étre la sienne. Il n'empêche que le souvenir de ce destin comblé ne nous rendra jamais la personnalité attachante de notre ami. Pas plus qu'il ne pourra la restituer à celle qui a perdu en le voyant partir bien plus que nous ne pourrons jamais perdre tous ensemble, son épouse, vers laquelle vont en ce moment toutes nos pensées affectueuses.

JacQues VANDERLINDEN Bruxelles, le 16 janvier 1973

Which of us at Rome, barely six weeks ago, could have imagined that in leaving him then it would be for ever? Who could have believed for a moment that the wonderful human warmth which he radiated could be suddenly extinguished without our being able to revive it? And yet we must resign ourselves to the fact that our friend Giuseppe Aurelio Costanzo will no longer be there to welcome us with that marvellous smile of his; and Rome, for many of us, will - despite all its attractions - no longer be quite the same. The International African Law Association has lost one of its most active Vice-Presidents and one of the most devoted to our common purpose, the Italian Section of I.A.L.A. has lost its tireless motive force, the Faculty of Political Science at the University of Perugia has lost a Dean whose period of office had proved itself rich in achievements of every kind; and finally we have all lost a dear friend. And still, his publications are there to recall to us the scholar so deeply interested in the development of African law, while the Conferences at Rome in I97I and 1972 testify to his determination to see his country take its proper place in this field. For all that, the memory of his rich achievement can never bring back to us the charming personality of our friend. No more than it can restore him to her who, in seeing him go, has lost more than all of us together, his wife, to whom our thoughts and sympathy go out at this time. 